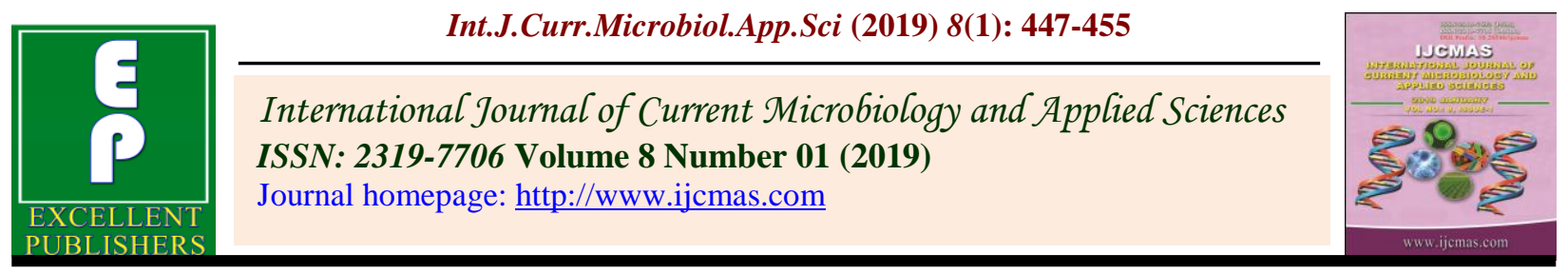

Original Research Article

https://doi.org/10.20546/ijcmas.2019.801.047

\title{
Morphological Variation and Chitinase Production Ability of Trichoderma viride Mutants
}

\author{
M.P. Vyawahare*, S.T. Ingle and A.G. Gathe \\ Department of Plant Pathology, Dr. Panjabrao Deshmukh Krishi Vidyapeeth, Akola- 444104 \\ (M.S.), India \\ *Corresponding author
}

\begin{tabular}{|c|c|}
\hline & A B S T R A C T \\
\hline $\begin{array}{l}\text { Ke y w o r d s } \\
\text { Morphological } \\
\text { variation, Chitinase } \\
\text { production, } \\
\text { Trichoderma viride, } \\
\text { Mutants }\end{array}$ & \multirow{3}{*}{$\begin{array}{l}\text { In an attempt to develop superior Trichoderma viride isolates for improvement in chitinase } \\
\text { Enzyme productivity, induction of mutants was applied. After application of different } \\
\text { concentrations of Ethyl methane sulfonate (EMS) and Hydroxyl amine (HA) treatments on } \\
\text { T.viride mutants were obtained. Trichoderma viride was determined by its physiological } \\
\text { state so that change in genetical conditions could alter the antagonism. Hence, the genetic } \\
\text { modification using mutagenesis offers the potential for producing improved bioprotection } \\
\text { is likely to enhance their biocontrol. Trichoderma viride mutants grown up to six } \\
\text { generations to check the stability on PDA and it was found variation in mutants compared } \\
\text { to mother culture. These mutants were tested for their chitinase productivity. TvME- } 4\left(\mathrm{~T}_{4}\right) \text {, } \\
\left.\text { TvMH-9 }\left(\mathrm{T}_{9}\right) \text { and TvME- } 3 \text { ( } \mathrm{T}_{3}\right) \text { mutants proved to be the highest producer of chitinase } \\
\text { enzyme, since it produced } 0.64,0.63 \text { and } 0.62 \text { enzyme units respectively, greater than the } \\
\text { mother culture. }\end{array}$} \\
\hline Article Info & \\
\hline $\begin{array}{l}\text { Accepted: } \\
\text { 04 December } 2018 \\
\text { Available Online: } \\
\text { 10 January } 2019\end{array}$ & \\
\hline
\end{tabular}

\section{Introduction}

Genetic transformation of existing biocontrol fungi that are well adjusted to their environment is likely to enhance their biocontrol capabilities. One attractive approach would be to select the stable and safe transgenic fungi with different genes coding for cell wall degrading enzymes (chitinase and glucanase) which express co-ordinately to combat the phytopathogen. Chitin, glucan and proteins are the main structural components of fungal cell wall. In plants, induction of chitinase, glucanase and other hydrolytic enzymes is one of the coordinated, often complex and multifaceted defence mechanism triggered in response to phytopathogen attack. But hydrolytic enzymes produced by plant itself are not sufficient to confer resistance to multiple pathogens. Fungal chitinases and glucanases appear to be more effective in their ability to inhibit pathogenic fungi than enzymes from other sources. As fungi play a major role in causing most of the plant diseases, genetic engineering of plants by transferring genes encoding chitinase and glucanase to develop plants resistant to fungal diseases is an approach of worth consideration.

Chitinases, $\beta$-1, 3- glucanases and proteases are the best studied antifungal proteins. 
Chitinase encoding genes are being used to improve plant defence against fungal pathogens. These enzymes are capable of degrading the linear homopolymer of $B-1,4-$ $\mathrm{N}$-acetyl- D glucosamine, the main cell wall component of most phytopathogenic fungi, showing strong inhibitory activity in vitro on spore germination and hyphal growth (Loritoet al., 1994).

\section{Materials and Methods}

Pure culture of Trichoderma viride, mother culture was received from the Department of Plant Pathology, Dr. P.D.K.V. Akola during 2018.

\section{Chemical mutagenesis}

Induction of Chemical mutagenesis was carried according to procedure suggested by Chandra et al., (2010) and Durand et al., (1988). Conidiospores of 8 days old culture of T. viride were used for mutagenesis. Spore suspension of $T$. viride was treated with Ethyl Methyl Sulphonate (EMS) and Hydroxyl Amine (HA)@50 $@ \mu 1 / \mathrm{ml}, 100 \mu \mathrm{l} / \mathrm{ml}, 150 \mu \mathrm{l} / \mathrm{ml}$, $200 \mu \mathrm{l} / \mathrm{ml}$ and $250 \mu \mathrm{l} / \mathrm{ml}$ and incubated at $28^{\circ} \mathrm{C}$ in orbital shaker for 30 minutes. Then kept in centrifuge machine at $5000 \mathrm{rpm}$ to remove the chemical traces, centrifuge it for three times and then washed with distilled water. Suspension was spread on to the surface PDA medium and incubated at $28^{\circ} \mathrm{C}$ for 72 hour. Procedure was done for 60 minutes. In each treatment maintained three replications. After incubation colonies were transferred on fresh PDA medium and grown up to six generations to check the stability of Trichoderma viride mutants.

\section{Experimental details}

The experiment was conducted in the laboratory bio-control efficacy of T.viride mutants under completely randomized design
(CRD) with treatment as $\mathrm{T}_{1}$ (TvME-1) - Spore suspension of T.viride treated with Ethyl methyl Sulphonate (EMS) @ $50 \mu \mathrm{l} / \mathrm{ml}$ for 60 minutes; $\mathrm{T}_{2}$ (TvME-2) - Spore suspension of T.viride treated with Ethyl methyl Sulphonate (EMS) @ $100 \mu 1 / \mathrm{ml}$ for 100 minutes; $\mathrm{T}_{3}$ (TvME-3) - Spore suspension of T.viride treated with Ethyl methyl Sulphonate (EMS) @ $150 \mu \mathrm{l} / \mathrm{ml}$ for 60 minutes; $\mathrm{T}_{4}$ (TvME-4) Spore suspension of T.viride treated with Ethyl methyl Sulphonate (EMS) @ $200 \mu \mathrm{l} / \mathrm{ml}$ for 60 minutes, $\mathrm{T}_{5}(\mathrm{Tv} \mathrm{ME}-5)$ - Spore suspension of T.viride treated with Ethyl methyl Sulphonate (EMS) @ $250 \mu \mathrm{l} / \mathrm{ml}$ for 60 minutes; $\mathrm{T}_{6}$ (TvMH-6) - Spore suspension of T.viride treated with Hydroxyl Amine (HA) @ $50 \mu \mathrm{l} / \mathrm{ml}$ for 60 minutes; $\mathrm{T}_{7}$ (TvMH-7) - Spore suspension of T.viride treated with Hydroxyl Amine (HA) @ $100 \mu \mathrm{l} / \mathrm{ml}$ for 60 minutes; $\mathrm{T}_{8}$ (TvMH-8) - Spore suspension of T.viride treated with Hydroxyl Amine (HA) @ 150 $\mu \mathrm{l} / \mathrm{ml}$ for 60 minutes; $\mathrm{T}_{9}(\mathrm{TvMH}-9)$ - Spore suspension of T.viride treated with Hydroxyl Amine (HA) @ $200 \mu \mathrm{l} / \mathrm{ml}$ for 60 minutes; $\mathrm{T}_{10}$ (TvMH-10) - Spore suspension of T.viride treated with Hydroxyl Amine (HA) @ 250 $\mu \mathrm{l} / \mathrm{ml}$ for 60 minutes; $\mathrm{T}_{11}$ (TvC-11) Untreated control i.e. $T$. viride mother.

\section{Preparation of colloidal chitin}

Colloidal chitin was prepared as per the method of Roberts and Selintrenikoff (1988).5 $\mathrm{g}$ of chitin powder (Hi-Media) was added slowly into $60 \mathrm{ml}$ of concentrated $\mathrm{HCl}(\mathrm{Sd}$. Fine Chemicals Ltd., Mumbai) and left for vigorous shaking overnight at $40^{\circ} \mathrm{C}$. The mixture was added to two liters of ice-cold 95 per cent ethanol with rapid stirring and kept overnight at room temperature $\left(25^{\circ} \mathrm{C}\right)$. The precipitate was collected by centrifugation at $5,000 \mathrm{~g}$ for 20 minutes at $4^{\circ} \mathrm{C}$ and then washed with sterile distilled water until the $\mathrm{pH}$ of the colloidal chitin turned neutral ( $\mathrm{pH} 7.0)$. Later, colloidal chitin solution (5 per cent) was prepared and stored at $4{ }^{\circ} \mathrm{C}$ for further use. 


\section{Preparation of phosphate Buffer (pH 6.7)}

Potassium Dihydrogen Phosphate $\left(\mathrm{KH}_{2} \mathrm{PO}_{4} 1\right.$ M) $136 \mathrm{gm}$ in $1000 \mathrm{ml}$ of distilled water. Potassium hypophosphate $\left(\mathrm{K}_{2} \mathrm{HPO}_{4} 1 \mathrm{M}\right) 174$ $\mathrm{gm}$ in $1000 \mathrm{ml}$ of distilled water. Both were mixed together and dilute up to required concentration $(50 \mathrm{mM})$ and $\mathrm{pH}$ should be maintained 6.7.

\section{Measurement of chitinase activity (Turbidity method)}

Endochitinase activity was measured by the reduction of turbidity of a suspension of colloidal chitin as per the method suggested by Kulkarni et al., (2010). A suspension containing $1 \%(\mathrm{w} / \mathrm{v})$ or moist colloidal chitin was prepared in $50 \mathrm{~mm}$ potassium phosphate buffer, $\mathrm{pH}$ 6.7. A mixture consisting of $0.5 \mathrm{ml}$ each of chitin suspension and the enzyme solution to be tested was prepared and inculcated for $24 \mathrm{~h}$ at $30^{\circ} \mathrm{C}$. Subsequently the mixture was diluted with $5 \mathrm{ml}$ and the optical density was read at $510 \mathrm{~nm}$. Enzyme activity was calculated as the percentage of reduction of a chitin suspension by 5 per cent. One min of enzyme activity (CU) is defined as release of $1 \mathrm{mMol} \mathrm{n}$-glucose acetyl amine/ $\mathrm{ml}$ culture filtrate $/ \mathrm{min} / \mathrm{mg}$ protein. $1 \mathrm{cu}=$ release of $1 \mathrm{~m}$ mol $\mathrm{N}$ - acetyl glucosamine/ $\mathrm{ml}$ of culture filtrate $/ \mathrm{mm} / \mathrm{mg} /$ protein.

\section{Preparation of standard graph}

The standard graph was constructed by using dextrose ('AR' grade) as glucose source. Standard solutions of glucose $(0.1,0.2,0.3$, $0.4,0.5,0.6,0.7,0.8,0.9$ and $1.0 \%$ ) were prepared. $0.5 \mathrm{ml}$ of each standard solution and chitin suspension were mixed in test tubes and incubated for $24 \mathrm{hr}$ at $30^{\circ} \mathrm{C}$. The absorbance at $510 \mathrm{~nm}$ was recorded using systronics make spectrophotometer after dilution with $5 \mathrm{ml}$ distilled water.

\section{Morphological study}

\section{Trichoderma viride (mother culture)}

Colony was milky white coloured at initial stage later turned dark green. subarial and dispersed growth was observed with moderate sporulation, giving yellow colour pigmentation on PDA medium. Phialides were grouped opposite with globose to obvoid shaped conidia, traditionally the isolates with warted conidia were identified as T. viride, Lieckfeldt et al., (1999) observed two morphologically distinct warted conidia Type-I and Type-II. The molecular studies (RFLP analysis of endochitinase gene, PCR finger printing and ITS analysis and rDNA) revealed that type - I corresponds to $T$. viride (Teleomorph- H. rufa) and Type II corresponds to $T$. asperellum and cannot be linked to teleomorph. T. asperellum was distinguished from $T$. viride by finer conidial ornamentation, slightly ovoidal conidia, a faster growth rate, mostly pared branches, ampulliform phialides and the consistent presence of chlamydospores (Samuels et al., 1999) (Table 1).

\section{Results and Discussion}

\section{Trichoderma viride mutants}

\section{TvME-1}

Subarial and dispersed growth was observed with moderate sporulation, colony was milky white at initial stage, later turned to dark green, colour dark yellow colour pigmentation on PDA medium, concentric rings were formed, phialides branched some have simple, conidiophores irregularly paired and subglobose roughened conidiation, conidia were globose to ellipsoidal. 


\section{TvME-2}

Colony milky white to light green mycelial growth at initial stage, later turned to light greyish green, aggregating at central region, subarial and dispersed was observed with moderate sporulation, concentric rings were produced on PDA medium, Dark yellow pigmentation was observed on PDA, phialides grouped simple, ellipsoidal shaped conidia.

\section{TvME-3}

Subarial and dispersed growth observed with maximum sporulation, colony milky white to light green mycelial growth at initial stage, later turned to dark green colour giving dark yellow colour pigmentation on PDA medium and concentric rings were formed, phialides were branched, ellipsoidal shape conidia were noticed under microscope.

\section{TvME-5}

Colony was milky white coloured at initial stage, later turned light green. flat and superficial growth observed This mutant slightly differed from other was fast growing forming concentric rings with maximum sporulation, colour of the medium changes with light yellow pigmentation on PDA, phialides were branched, conidia roughened, globose to ellipsoidal shape conidia.

\section{TvME-5}

Flat and superficial growth was observed with moderate sporulation, colony was milky white at initial stage, later turned to dark green, giving dark yellow colour pigmentation on PDA medium, phialides were grouped simple with ellipsoidal shaped conidia.

\section{TvMH-6}

Colony was milky white coloured at initial stage, later turned to light green with moderate sporulation, and giving light yellow pigmentation on PDA medium. subarial and dispersed growth was observed, phialides were grouped simple, a conidia were ellipsoidal in shape.

\section{TvMH-7}

Colony was milky white coloured at initial stage, later turned to light green with moderate sporulation, giving light yellow colour pigmentation on PDA medium, subarial and dispersed growth was observed, phialides were branched, conidia was ellipsoidal in shape

\section{TvMH-8}

Colony was milky white coloured at initial stage later turned to dark green, concentric rings, fast growing and maximum sporulation with light yellow colour pigmentation was observed, phialides were branched, conidia globose to ellipsoidal in shape.

\section{TvMH-9}

Subarial and dispersed growth was observed with maximum sporulation, colony was dark grey at initial stage, later turned to light green, colour dark yellow colour pigmentation on PDA medium, concentric rings were formed, phialides grouped some have simple and subglobose roughened conidiation, conidia ellipsoidal shape.

\section{TvMH-10}

Colony was milky white coloured at initial stage, later turned to light green with maximum sporulation, giving dark yellow colour pigmentation on PDA medium. Subarial and dispersed growth was observed, phialides were grouped simple, subglobose roughened conidiation, conidia was ellipsoidal in shape. 
Table.1 Morphological characteristics of Trichoderma viride mother culture and mutants $\left(7^{\text {th }}\right.$ generation)

\begin{tabular}{|c|c|c|c|c|c|c|c|c|}
\hline \multirow[t]{2}{*}{ Sr.no } & \multirow{2}{*}{$\begin{array}{c}\text { Trichoderma } \\
\text { viride } \\
\text { mutants }\end{array}$} & \multicolumn{7}{|c|}{ Morphological characters } \\
\hline & & $\begin{array}{c}\text { Colony } \\
\text { diameter/Radial } \\
\text { mycelial } \\
\text { growth }(\mathrm{mm}) \text { at } 7 \\
\text { DAI }\end{array}$ & $\begin{array}{l}\text { Colony } \\
\text { growth } \\
\text { type }\end{array}$ & $\begin{array}{l}\text { Colony } \\
\text { colour }\end{array}$ & $\begin{array}{c}\text { Pigment } \\
\text { ation }\end{array}$ & Phialides & $\begin{array}{l}\text { Conidia } \\
\text { shape }\end{array}$ & $\begin{array}{l}\text { Spor } \\
\text { u } \\
\text { latio } \\
n\end{array}$ \\
\hline 11 & TvC-11 & 90.00 & $\begin{array}{l}\text { Subarial } \\
\text { and } \\
\text { dispersed }\end{array}$ & $\begin{array}{c}\text { Milky } \\
\text { white to } \\
\text { dark green }\end{array}$ & Yellow & $\begin{array}{l}\text { Grouped } \\
\text { opposite }\end{array}$ & $\begin{array}{c}\text { Globose to } \\
\text { obvoid }\end{array}$ & ++ \\
\hline 1 & TvME-1 & 88.50 & $\begin{array}{l}\text { Subarial } \\
\text { and } \\
\text { dispersed }\end{array}$ & $\begin{array}{c}\text { Milky } \\
\text { white to } \\
\text { Darkgreen }\end{array}$ & $\begin{array}{c}\text { Dark } \\
\text { Yellow }\end{array}$ & Branched & $\begin{array}{l}\text { globose to } \\
\text { ellipsoidal }\end{array}$ & ++ \\
\hline 2 & TvME-2 & 90.00 & $\begin{array}{l}\text { Subarial } \\
\text { and } \\
\text { dispersed }\end{array}$ & $\begin{array}{c}\text { Milky } \\
\text { white to } \\
\text { light green }\end{array}$ & $\begin{array}{c}\text { Dark } \\
\text { Yellow }\end{array}$ & $\begin{array}{c}\text { Grouped } \\
\text { simple }\end{array}$ & Ellipsoidal & ++ \\
\hline 3 & TvME-3 & 89.00 & $\begin{array}{l}\text { Subarial } \\
\text { and } \\
\text { dispersed }\end{array}$ & $\begin{array}{c}\text { Milky } \\
\text { white to } \\
\text { light green }\end{array}$ & $\begin{array}{c}\text { Dark } \\
\text { Yellow }\end{array}$ & Branched & Ellipsoidal & +++ \\
\hline 4 & TvME-4 & 90.00 & $\begin{array}{c}\text { flat and } \\
\text { superficia } \\
1\end{array}$ & $\begin{array}{l}\text { Milky } \\
\text { white to } \\
\text { light green }\end{array}$ & $\begin{array}{l}\text { Light } \\
\text { Yellow }\end{array}$ & Branched & $\begin{array}{l}\text { globose to } \\
\text { ellipsoidal }\end{array}$ & +++ \\
\hline 5 & TvME-5 & 89.50 & $\begin{array}{c}\text { flat and } \\
\text { superficia } \\
1\end{array}$ & $\begin{array}{c}\text { Milky } \\
\text { white to } \\
\text { Darkgreen }\end{array}$ & $\begin{array}{c}\text { Dark } \\
\text { Yellow }\end{array}$ & $\begin{array}{c}\text { Grouped } \\
\text { simple }\end{array}$ & Ellipsoidal & ++ \\
\hline 6 & TvMH-6 & 89.57 & $\begin{array}{l}\text { Subarial } \\
\text { and } \\
\text { dispersed }\end{array}$ & $\begin{array}{c}\text { Milky } \\
\text { white to } \\
\text { light green }\end{array}$ & $\begin{array}{l}\text { Light } \\
\text { Yellow }\end{array}$ & $\begin{array}{l}\text { Grouped } \\
\text { simple }\end{array}$ & Ellipsoidal & ++ \\
\hline 7 & TvMH-7 & 89.70 & $\begin{array}{l}\text { Subarial } \\
\text { and } \\
\text { dispersed }\end{array}$ & $\begin{array}{c}\text { Milky } \\
\text { white to } \\
\text { light green }\end{array}$ & $\begin{array}{l}\text { Light } \\
\text { Yellow }\end{array}$ & Branched & Ellipsoidal & ++ \\
\hline 8 & TvMH-8 & 90.00 & $\begin{array}{l}\text { Subarial } \\
\text { and } \\
\text { dispersed }\end{array}$ & $\begin{array}{c}\text { Milky } \\
\text { white to } \\
\text { Darkgreen }\end{array}$ & $\begin{array}{l}\text { Light } \\
\text { Yellow }\end{array}$ & Branched & $\begin{array}{l}\text { globose to } \\
\text { ellipsoidal }\end{array}$ & +++ \\
\hline 9 & TvMH-9 & 89.50 & $\begin{array}{l}\text { Subarial } \\
\text { and } \\
\text { dispersed }\end{array}$ & $\begin{array}{l}\text { Dark grey } \\
\text { to light } \\
\text { green }\end{array}$ & $\begin{array}{c}\text { Dark } \\
\text { Yellow }\end{array}$ & $\begin{array}{l}\text { Grouped } \\
\text { simple }\end{array}$ & Ellipsoidal & +++ \\
\hline 10 & TvMH-10 & 90.00 & $\begin{array}{l}\text { Subarial } \\
\text { and } \\
\text { dispersed }\end{array}$ & $\begin{array}{c}\text { Milky } \\
\text { white to } \\
\text { light green }\end{array}$ & $\begin{array}{c}\text { Dark } \\
\text { Yellow }\end{array}$ & $\begin{array}{c}\text { Grouped } \\
\text { simple }\end{array}$ & Ellipsoidal & +++ \\
\hline
\end{tabular}


Table.2 Chitinase enzyme units in $T$. viride mother culture and mutants

\begin{tabular}{|c|c|c|}
\hline Treatments & Code name & Chitinase enzyme units/ mg of protein \\
\hline $\mathbf{T}_{\mathbf{1}}$ & TvME-1 & $0.37(0.61)^{*}$ \\
\hline $\mathbf{T}_{\mathbf{2}}$ & TvME-2 & $0.52(0.72)$ \\
\hline $\mathbf{T}_{\mathbf{3}}$ & TvME-3 & $0.62(0.79)$ \\
\hline $\mathbf{T}_{\mathbf{4}}$ & TvME-4 & $0.64(0.80)$ \\
\hline $\mathbf{T}_{\mathbf{5}}$ & TvME-5 & $0.60(0.78)$ \\
\hline $\mathbf{T}_{\mathbf{6}}$ & TvMH-6 & $0.41(0.64)$ \\
\hline $\mathbf{T}_{\mathbf{7}}$ & TvMH-7 & $0.57(0.75)$ \\
\hline $\mathbf{T}_{\mathbf{8}}$ & TvMH-8 & $0.61(0.78)$ \\
\hline $\mathbf{T}_{\mathbf{9}}$ & TvMH-9 & $0.63(0.79)$ \\
\hline $\mathbf{T}_{\mathbf{1 0}}$ & TvMH-10 & $0.60(0.78)$ \\
\hline $\mathbf{T}_{\mathbf{1 1}}$ & TvC-11 & $0.38(0.62)$ \\
\hline & 'F' test & sig \\
\hline & SE(m) \pm & 0.01 \\
\hline & $\mathrm{CD}(\mathrm{P}=0.01)$ & 0.05 \\
\hline
\end{tabular}

*Figure in the parentheses are square root transformed values

**Chitinase enzyme estimate value on spectrophotometer at $510 \mathrm{~nm}$ wavelength

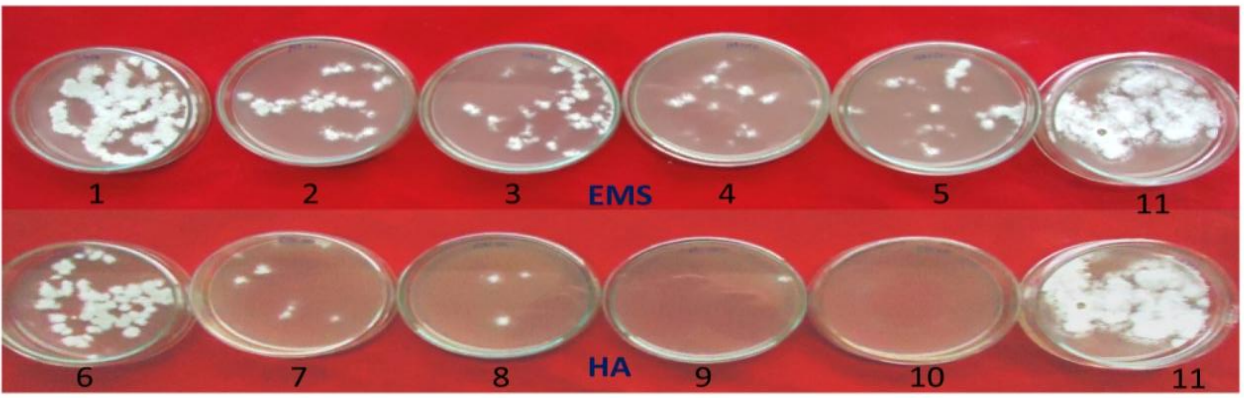

Plate 1a. Trichoderma viride mutants and mother culture 1 st after treatment

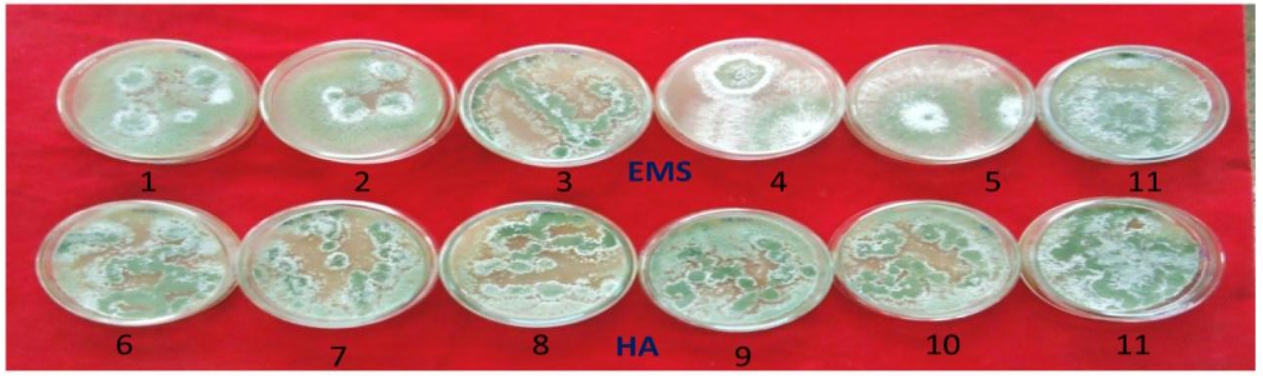

Plate 1b. Trichoderma viride mutants and mother culture 7 th after treatment 


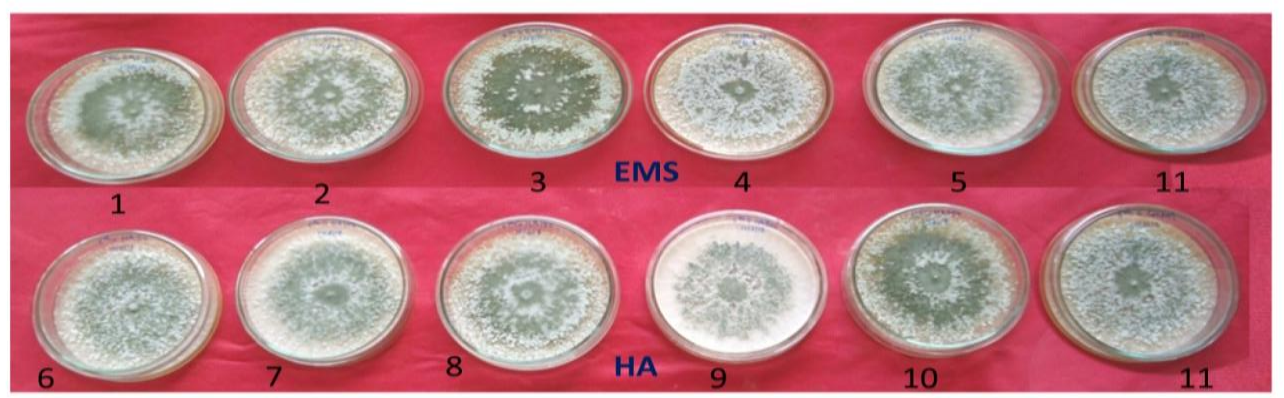

Plate 4a. Trichoderma viride mutants and mother culture 6 th generation

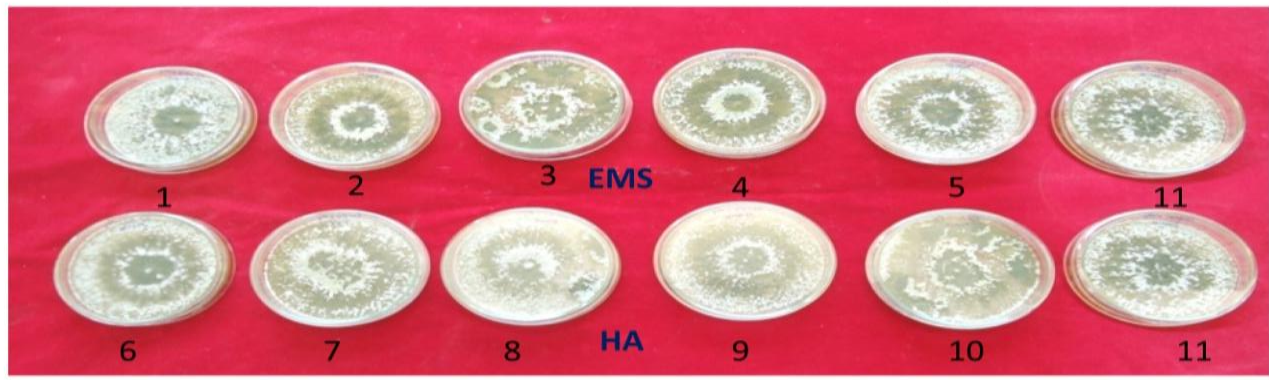

Plate 4b. Trichoderma viride mutants and mother culture 7 th generation

The genus Trichoderma Pers.:Fr. is defined to include anamorphs of Hypocrea, having elongated phialides and irregularly branched conidiophores Rifai (1969).

Visual appearance of Trichoderma on plates exhibited fast growing flat, superficial or subaerial mycelial growth, forming mostly concentric rings or discreet, disperse or some isolates producing good aerial and congregated growth at central and peripheral regions, conidiophores in Trichoderma is repeatedly branched at an indefinite number of levels with the primary branches producing smaller secondary branches that also may branch and at higher levels apically and distally progressively shorter. Phialides are ampuliform to lageniform, usually constricted at the base, more or less swollen near the middle. Phialides are disposed in verticilster minally on branches of the conidiophore.

Conidia are hyaline or more usually green, smooth walled in $T$. harzianum and roughened in $T$. viride. And conidia shape varies from globose, to ellipsoidal, obovoidal, or short-cylindrical, with the basal end more or less tapering and truncate. Similar type of morphological characters was also observed by Rifai (1969), Bissett (1991a, 1991b). Most isolates of $T$. viride produced characteristic dark red/or red to light, yellow pigmentation in media also corroborates the results of present studies.

Selvakumar (2000) also showed stable colony characters of $T$. viride in UV light and EMS induced mutants which differ from a parent strain.

Haggag (2002) carried out mutagenesis of Trichoderma harzianum and T. koningii with 50 and 75 kilo-rad doses of gamma which result four mutants of each $T$. harzianum and T. koningii capable of producing high level of chitinase. These mutants were stable and superior to wild type (WT) with respect to growth, sporulation and potential against $B$. cinerea.

Mohamed and Haggag (2002) mutagenesis of three Trichoderma spp. With 20 and 40 kilo- 
rad doses of gamma and reported four mutants of each spp. Including $T$. harzianum, $T$. viride and $T$. koningi were obtained by gamma irradiation to enhance their biocontrol abilities against $S$. cepivorum and their production of antifungal metabolites.

Mohamed et al., (2002) reported that mutant species of exhibited high capabilities to produce many efficient enzymes and other metabolites with better control of onion whit rot disease.

Induced mutation is one of the most widely used tools to get variants which might have improved biocontrol properties like survival ability, antagonistic and biocontrol potential and ability to colonize plant parts (Baker, 1991).

Chitinase enzyme units in Trichoderma viride mother culture and mutants

The data presented in table 2, showed that TvME-4 $\left(\mathrm{T}_{4}\right)$ content maximum i.e. 0.64 chitinase enzyme units/ $\mathrm{mg}$ of protein units followed by TvMH-9 ( $\left.\mathrm{T}_{9}\right)$ and only TvME-3 $\left(T_{3}\right)$ i.e. 0.63 and 0.62 . The next best mutants were (TvMH-8) (T $)$, TvME-5 $\left(\mathrm{T}_{5}\right)$ and TvMH-10 $\left(\mathrm{T}_{10}\right)$ which contain $0.62,0.60$ and 0.60 chitinase enzyme units/mg of protein unit respectively. TvMH-7 $\left(\mathrm{T}_{7}\right)$, and TvME-2 $\left(\mathrm{T}_{2}\right)$ were at par with each other. $T$. viride mother culture contain 0.38 and the lowest chitinase enzyme units were estimated in TvME-1 $\left(\mathrm{T}_{1}\right)$ i.e. 0.37 enzyme units/mg of protein.

Haggag and mohamad (2002) carried out mutagenesis of $T$. harzianum and $T$. koningii with 50 and 75 kilo-rad doses of gamma irradiation which resulted four mutants of each $T$. harzianum and $T$. koningii capable of producing high level of chitinase. These mutants were stable and superior to wild type (WT) with respect to growth, sporulation and biocontrol potential against $B$. cinerea. The fast growing characteristics of different mutants with expression the high units of chitinase enzyme reflected in maximum inhibitory ability of test pathogens. i.e. $S$. rolfsii, $R$. bataticola, $F$. solani and F.udum. Present studies proved the earlier reports in respect to mutants' activities

Zaldivar et al., (2001) treated T. aureoviride strains with $\mathrm{N}$ methyl- N-nitro-Nnitrosoguanidine. The mutant strains showed enhanced production of fungal cell wall degrading enzymes i.e. chitinase, $\beta-1,3-$ glucanases and proteases.

Kulkarni and Ramanujan et al., (2010) also studied the ability of Trichoderma isolates to produce chitinase enzyme through polyacrailamide gel electrophoresis (SDSPAGE) method related to their antagonistic ability will help to identify the markers and it can be inserted in to the plant itself through genetic engineering to evolve resistant varieties or these markers may be inserted into Trichoderma species itself to promote its antagonistic ability.

\section{References}

Baker, R. 1991. Induction of Rhizosphere competence of benomyl tolerant mutants of Trichoderma spp. Can. J. Microbiol. 34:694-696.

Chaudhary M. 2009. Bioinsensitive management of collar rot affecting tropical sugar beet with biopesticides NIPROT (Trichoderma viride) and Su-Mona (Pseudomonas fluroscencens). 99(6): 522.

Gadgil N.J., Daginawala, H.F., Chakrabarti, T. and Khanna, P. 1995. Enhanced cellulose production by a mutant of Trichoderma reesei. Enzyme and Microbial tech. (17):10s,

Haggag, W.M. and Mohamed, H.A. 2002. 
Enhancement of antifungal metabolite production from gamma-ray induced mutants of some Trichoderma species for control of onion white rot disease. Pl. Pathol. Bull. 11: 45-56 942-946.

Lorito, M., Harman, G. E., Hayes, C. K., Broadway, R. M., Tronsmo, A., Woo, S. L. and DiPietro, A. 1993. Chitinolytic enzymes produced by Trichoderma harzianum: antifungal activity of purified endochitinase and chitobiosidase. Phytopathology 83: 302-307.

Migheli, Q., L. Gonzalez-Candelas, L. Dealessi, A. Camponogara and Ramon-vidal, D. 1998. Transformants of Trichoderma longibrachiatum over expression the a-1,4- endoglucanase gene egl1 show enhanced biocontrol of Pythium ultimum on cucumber. Phytopathol. 88: 673-677.

Mohamed, H. A. A., Wafaa, M. Haggag and Attallah, A. G. 2010.Genetic enhancement of Trichoderma viride to overproduce different hydrolytic enzymes and their biocontrol potentiality against root rot and white mold diseases in plants. Agric. Biol. J.
N. Am 1 (3): 273-284.

Papavizas, G. C., 1985: Trichoderma and Gliocladium: biology, ecology, and potential for biocontrol. Ann. Review Phytopath., 23: 23-54.

Roberts, W. K. and Selitrennik, C. P. 1988. Plant and Bacterial Chitinases Differ in Antifungal Activity. Journal of' General Microbiology, 134: 169-176.

Savita Wagh, S.T. Ingle., S. Dandale and S.S. Mane, 2015. Improvement in biocontrol ability of Trichoderma viride through gamma irradiation. Trends in Biosciences., 8(20): 56225626.

Shripad Kulkani., B, R.J Ramanujam, M. Rabindra. Nagesh and N. R. Roa. 2010. Isolation, identification and documentation of efficient chitinase enzyme production ability strains of Trichoderma. J. Pl. Dis. Sci. 5(1) 2010: 198-202.

Suryawanshi, K., Ingle, S. T., Shingote, P.R. and Chaudhari, S.R. 2013. Chitinase production ability of Trichoderma viride mutants. Bioinfotech 10(3B): 1048-1050

\section{How to cite this article:}

Vyawahare, M.P., S.T. Ingle and Gathe, A.G. 2019. Morphological Variation and Chitinase Production Ability of Trichoderma viride Mutants. Int.J.Curr.Microbiol.App.Sci. 8(01): $447-$ 455. doi: https://doi.org/10.20546/ijcmas.2019.801.047 